\title{
PROBLEMATYKA FILOZOFICZNYCH PODSTAW PEDAGOGIKI W SPORZE WYDZIAŁU FILOZOFII CHRZEŚCIJAŃSKIEJ KUL Z MARKSIZMEM
}

\author{
The Philosophical Foundations of Pedagogy in the Dispute of The Faculty \\ of Christian Philosophy of the Catholic University of Lublin with \\ Marxism
}

Summary: The article deals with the philosophical foundations of alternative pedagogy in relation to Marxism. The subject of these reflections are the research activities carried out by the Department of Christian Philosophy of the Catholic University of Lublin (KUL) during the time of communist rule in Poland. Thanks to the philosophical anthropology formulated at the department, it could, independently of the ideological indoctrination connected with the contemporaneous system of power, find its own necessary theoretical foundation.

The paper is comprised of four parts. The first part presents the political realities of the dialogue. It is well known that KUL - the only Catholic university in any communist country - was an important center of Christian culture in Poland and that it implemented a model of education based on Christian values, even though it operated under strong pressure from the authorities of the People's Republic of Poland. The second part of the paper covers the five stages of the running dialogue between philosophers at KUL and Marxists, an exchange particularly colored by the political changes that occurred in Poland in the years 1944, 1950, 1956, 1968, 1981, and 1989. The third part of the analysis is devoted to the model of integral humanism realized by KUL, with particular attention being paid to the role of research conducted in the Department of Philosophy. The article concludes with a discussion of the theses of philosophical anthropology formulated at the Catholic University of Lublin, selected for their differences regarding the three fundamental determinants of Marxism: materialism, atheism, and dialectics.

${ }^{1}$ Dr hab. Maria Małgorzata Boużyk - adiunkt w Katedrze Filozofii Wychowania Wydziału Nauk Pedagogicznych Uniwersytetu Kardynała Stefana Wyszyńskiego w Warszawie. Adres: WNP UKSW, ul. Wóycickiego 1/3, bud. 15, 01-938 Warszawa; e-mail: m.bouzyk@uksw.edu.pl. 
Keywords: Marxism, Thomism, pedagogy, philosophical anthropology, integral humanism, The Department of Christian Philosophy of the Catholic University of Lublin

Sformułowane przez badaczy Wydziału Filozofii Chrześcijańskiej KUL ${ }^{2}$ w czasach PRL filozoficzne podstawy pedagogiki alternatywnej w stosunku do pedagogiki marksistowskiej miały mocne determinanty w rzeczywistości politycznej tamtego okresu. Dlatego ograniczenie się do przedstawienia filozoficznych tez właściwych środowisku KUL-u jest niewystarczające, ponieważ nie oddaje heroizmu zmagań: odwagi i uczciwości intelektualnej osób zaangażowanych w dyskusję z marksizmem. Trudność merytorycznej argumentacji wynikała z silnego komponentu ideologicznego marksizmu oraz instrumentalnego traktowania go przez władze komunistyczne. Nie można więc pominąć politycznego kontekstu sporu, tym bardziej że miał on wpływ również na rozwój marksizmu.

Aby oddać historyczną wagę trwającej przez blisko 40 lat dyskusji, dobrze jest ponadto pamiętać, że wydział realizował misję uniwersytetu, którego był częścią. Katolicki Uniwersytet Lubelski stał się po wojnie ważnym centrum kultury chrześcijańskiej. Działalność reaktywowano tu w 1944 roku, a więc jeszcze w trakcie działań wojennych, za przyzwoleniem władzy ludowej, wykorzystującej ten fakt dla własnych celów propagandowych. Chodziło o zdobycie przychylności Kościoła i polskiego społeczeństwa, w dużej części przecież katolickiego. Pod pozorami życzliwości krył się jednak - właściwy marksizmowi - programowy plan walki z religią.

Biorąc pod uwagę nie tylko merytoryczną stronę dialogu, ale także wspomniane uwarunkowania, przyjrzymy się problemowi pod kątem czterech kwestii: realiów politycznych dialogu, kolejnych jego etapów, modelu humanizmu realizowanego przez KUL (z zaznaczeniem roli badań prowadzonych na Wydziale Filozofii), wybranych tez antropologii filozoficznej jako podstawy pedagogiki. Środowisko naukowe KUL-u odwoływało się do modelu wychowania utrwalonego wielowiekową tradycją kultury chrześcijańskiej i antycznej, a osią toczonego sporu była filozoficzna koncepcja człowieka. Należy jednak podkreślić, że debata dotyczyła różnic nie tylko na poziomie tez antropologicznych, ale także metafizycznych jako zasadniczego fundamentu koncepcji człowieka. Rozumienie bytu, jak podkreślali filozofowie KUL-u, warunkuje rozumienie człowieka: terminy metafizyki stosuje się do interpretacji faktu ludzkiego. Znaczenie nowatorskich badań w dziedzinie metafizyki prowadzonych przez wydział umyka zazwyczaj uwadze pedagogów, zainteresowanych, co zrozumiałe, treściami antropologicznymi. Tymczasem dyskusja z materializmem dialektycznym i historycznym oraz ateizmem warunkującymi marksistowską pedagogikę wymagała poszerzenia wiedzy z zakresu zarówno antropologii, jak i metafizyki.

\footnotetext{
2 Dalej używam skrótu „WFCh” bądź określenia „Wydział Filozofii KUL”.
} 
W związku z tym, że spór z marksizmem, który toczyli naukowcy wydziału, odsłaniał zasadnicze różnice $\mathrm{w}$ filozoficznych podstawach pedagogiki, możemy mówić o dwóch alternatywnych jej modelach: marksistowskim i tomistycznym. Warto jednak zauważyć, że formułowanie pedagogiki alternatywnej do marksistowskiej mogło znaleźć oparcie nie tylko w filozofii tomistycznej, którą uprawiano na KUL-u, ale także w długiej polskiej tradycji akademickiej: filozofia okresu międzywojnia rozwijała się wielokierunkowo.

\section{Realia polityczne dialogu}

Dialog z marksizmem trudno było budować na zasadach tolerancji, ponieważ marksiści programowo je odrzucali O ile w kulturze chrześcijańskiej podstawowym wyznacznikiem relacji międzyludzkich jest przykazanie miłości bliźniego, to marksiści, przynajmniej w oficjalnych wystąpieniach, podkreślali „walkę klas” i różne fronty walki ${ }^{3}$. W celu zobrazowania skali trudności trwającej niemal pół wieku dyskusji można przytoczyć wypowiedź o. Józefa M. Bocheńskiego oceniającego radziecką pierestrojkę: „marksiści-leniniści są w dialogu programowo nieuczciwi [...] i wcale się z tym nie kryją. Lenin powiedział; »dobre jest to, co służy do zburzenia świata [ [...]. Partia komunistyczna istnieje i działa wyłącznie po to, żeby swoją ideologię narzucić światu"4. Moralność w marksizmie była kategorią klasową i historycznie zmienną, tj. zdeterminowaną przez bazę ekonomiczną: w warunkach gospodarki kapitalistycznej rządzący stosowali swoje zasady moralne, Gdy do władzy doszedł proletariat, dobre stawało się to, co służyło jego rządom, a wszystko, co przeszkadzało, było złem ${ }^{5}$. Ta zasada była stosowana także wobec instytucji takich jak KUL, który odwoływał się do innego niż marksistowski kanonu wartości.

Uniwersytet znalazł się więc pod silną presją ze strony władz PRL ${ }^{6}$. Funkcjonowanie utrudniano mu na różne sposoby. Na przykład zabraniano przyjmowania kandydatów na I rok studiów na tych kierunkach, które w procesie kształcenia mogły formować młodzież w duchu sprzecznym z zasadami panującego ustroju. Takim restrykcjom poddano Wydział Prawa i Nauk Społeczno-Ekonomicznych (1949), Studium Zagadnień

${ }^{3}$ Zob. Mieczysław A. Krąpiec, „Dialog?”, w: Wobec filozofii marksistowskiej. Polskie doświadczenia, red. Antoni B. Stępień (Lublin: TN KUL 1990), 10.

${ }^{4}$ Józef M. Bocheński, Marksizm-leninizm. Nauka czy wiara? (Komorów: Wyd. „Antyk - Marcin Dybowski" 1999), 5.

${ }^{5}$ Zob. Karol Marks, Fryderyk Engels, „Ideologia niemiecka”, w: Dzieła, t. 3 (Warszawa: Książka i Wiedza 1961), 268 [podaję za: Stanisław Kowalczyk, Człowiek w poszukiwaniu wartości. Elementy aksjologii personalistycznej (Lublin: Wyd. KUL 2006), 88].

${ }^{6}$ Zob. hasło „Historia KUL”, http://www.kul.pl/w-polsce-ludowej,art_15518.html, dostęp: 10.04.2017. 
Społecznych i Gospodarczych Wsi (1951) oraz pedagogikę (1953), co doprowadziło do jej likwidacji (powróciła dopiero w roku 1981). W 1953 roku Wydziałowi Humanistycznemu odebrano prawo przeprowadzania przewodów doktorskich i habilitacyjnych (przywrócono je w 1977 roku), pracownicy tego wydziału zatem stopnie naukowe musieli zdobywać na uczelniach państwowych, przy czym z zatwierdzeniem habilitacji zwlekano często przez kilka, a nawet kilkanaście lat. Blokowano także naukowe wyjazdy zagraniczne, limity studentów wyznaczone zostały przez władze państwowe, absolwentom uczelni odmawiano zatrudniania w instytucjach państwowych, publikacje naukowe cenzurowano, wprowadzono zakaz działalności organizacji młodzieżowych, rekwirowano wiele należących do KUL-u budynków oraz terenów, a społeczność uniwersytecką poddawano stałej inwigilacji tajnych służb. Mimo to uczelnia stanęła w obronie fundamentalnych wartości, już choćby $\mathrm{w}$ tym sensie tworząc zręby pedagogiki alternatywnej wobec marksistowskiej.

Ważna rola przypadła w tym procesie filozofom KUL-u, między innymi ze względu na ich dyskusję z marksistami wokół kwestii antropologicznych, najistotniejszych dla każdego modelu wychowania. Historia tego dialogu była oczywiście naznaczona sytuacją polityczną w kraju, determinującą również rozwój marksizmu. Wyróżnia się następujące okresy: 1944-1949, 19491956, 1956-1968, 1968-1980 i 1980-1989.

\section{Etapy dialogu z marksistami}

Przystępując do krótkiej charakterystyki pięciu wymienionych etapów, należy zaznaczyć, że dialog zasadniczo rozpoczyna się dopiero po przełomie październikowym 1956 roku. W pierwszym okresie (1944-1949) filozofia marksistowska nie była jeszcze gotowa do rozmowy, a i Wydział Filozofii KUL znajdował się w fazie organizacyjnej (rozpoczął działalność dopiero 10 listopada $1946 \mathrm{roku}$ ). Jakkolwiek wkrótce stał się "matecznikiem” tomizmu, filozofii odsłaniającej zdecydowanie alternatywny do marksistowskiego obraz człowieka i rzeczywistości, to w pierwszych powojennych latach dyskusję z marksizmem z perspektywy tomistycznej podjął ośrodek krakowski - ks. Kazimierz Kłósak, przyszły profesor KUL. W swoich pracach Materializm dialektyczny. Studia krytyczne (1948) oraz Myśl katolicka wobec teorii samorództwa (1948) krytycznie oceniał główne prawa dialektyki, niektóre rozwiązania kosmologiczne,

7 Szczegółowe opracowanie ze strony filozofów KUL można znaleźć na przykład w artykułach Antoniego B. Stępnia („Rys rozwoju filozofii marksistowskiej i problem dialogu filozoficznego z marksizmem od roku 1945”, w: Wobec filozofii marksistowskiej, 21-59) czy Wojciecha Chudego („Postaci marksizmu i ich ewolucja w powojennej Polsce”, w: Oblicza dialogu. Z dziejów i teorii dialogu: chrześcijanie - marksiści w Polsce, red. Antoni B. Stępień, Tadeusz Szubka (Lublin: RW KUL 1992), 91-112). 
na przykład problem wieczności wszechświata oraz implikacje światopoglądowe tej formy monizmu materialistycznego.

Trzeba pamiętać, że do 1950 roku filozofia polska istniała w kształcie podobnym do przedwojennego: swoją aktywność wznowiły dawne instytucje i periodyki, wydawano książki, a w uniwersytetach pracę podjęli między innymi profesorowie: Kazimierz Ajdukiewicz, Tadeusz Kotarbiński, Tadeusz Czeżowski, Izydora Dąbska, Maria i Stanisław Ossowscy, Władysław Tatarkiewicz, Roman Ingarden. W tym czasie marksizm, bez poważniejszych tradycji akademickich, $\mathrm{z}$ trudem walczył o swoją pozycję wśród innych kierunków filozoficznych. Jak zauważa Wojciech Chudy, filozof KUL, ten „szczep intelektualny”, mimo przywilejów politycznych nie przyjmował się łatwo na gruncie polskim, a komponenta ideologiczna działała na jego niekorzyść ${ }^{8}$. Ze znaczących publikacji marksistowskich tego okresu można wymienić Wstęp do teorii marksizmu Adama Schaffa. W dyskusję z marksistami angażowały się takie czasopisma, jak "Tygodnik Powszechny”, „Znak”, „Przegląd Powszechny”, „Odrodzenie”.

Jak wiadomo, pod koniec lat 40. XX wieku atmosfera polityczna nie sprzyjała swobodnej wymianie poglądów, a dialog $\mathrm{z}$ marksizmem stawał się pozorny: władze traktowały go czysto instrumentalnie, wykorzystując do własnych ideologicznych celów. Tak zwany okres stalinowski (do 1956 roku) był czasem silnego zideologizowania ośrodków akademickich. Marksizm-leninizm (stalinowska wykładnia marksizmu) stał się wtedy „filozofią urzędową "10, a filozofowanie sprowadzone do ślepego posłuszeństwa dogmatowi trudno było nazwać rzeczywistym procesem poznawczym. Śladu filozoficznego dyskursu można dopatrywać się we fragmentach $Z$ zagadnień marksistowskiej teorii prawdy (1951) Adama Schaffa ${ }^{11}$. Dyskusja marksistów miała charakter pozorowany, była też mocno naznaczona światopoglądowo, czego dowodem są na przykład publikacje Schaffa, Bronisława Baczki, Tadeusza Krońskiego czy Leszka Kołakowskiego, zawarte w „Myśli Filozoficznej", będące de facto atakami na profesorów niemarksistowskich. Dla marksizmu cała rzeczywistość (w tym człowiek) była przejawem dialektycznego rozwoju materii. Systemową konsekwencję stanowił materializm historyczny, a w rezultacie zgoda na relatywizm aksjologiczny, a także zmienność teorii moralności, które - zdaniem marksistów - były wytworem sytuacji ekonomicznej w określonym momencie historycznym ${ }^{12}$. Według marksistów żadna stała moralność nie istniała, a klasyczne wartości kultury: prawda, dobro, piękno, świętość przestawały być wyznacznikami w modelu wychowania „nowego człowieka”.

Chrześcijaństwo, głosząc równość wszystkich ludzi wobec Boga, postrzegało wolność jako naturalny atrybut ludzkiego bytu i prawo każdej osoby, marksizm

${ }^{8}$ Zob. Chudy, „Postaci marksizmu”, 93.

9 Zob. tamże, 94.

10 Zob. tamże, 95.

11 Zob. tamże.

12 Zob. Karol Marks, Fryderyk Engels, Manifest komunistyczny (Warszawa: Jirafa Roja 2011). 
problem równości odrywał od sfery moralnej i wiązał z rzeczywistością społecznych działań ( $w$ tym ze stosowaniem rewolucyjnej przemocy). Chrześcijański nakaz miłości bliźniego - zdaniem marksistów - nie dawał się uzgodnić z aksjologią opartą na materializmie historycznym i wymogami humanizmu walczącego. Schaff, próbując włączyć kategorię miłości do marksizmu, kojarzył ją wtedy $\mathrm{z}$ nienawiścią wroga klasowego ${ }^{13}$.

Kolejna kwestią, ważną dla problemu antropologii i pedagogiki alternatywnej wobec marksizmu jest interpretacja relacji jednostki do społeczeństwa. Marksistowski kolektywizm uznawał bytowy i aksjologiczny prymat społeczności nad jednostką, z czym łączył się postulat poddania obywateli ścisłej kontroli państwa ${ }^{14}$. Jak zauważa Stanisław Kowalczyk, jeden z profesorów WFCh, teza ta miała znaczące konsekwencje aksjologiczne: „Jeżeli człowiek staje się człowiekiem dopiero w wyniku podjęcia życia społecznego, jak sugeruje marksizm, to proces socjalizacji jest istotną podstawą do uznania równości [wszystkich ludzi - przyp. aut.]"15.

W okresie stalinowskim Wydział Filozofii KUL, podobnie jak i cała uczelnia, był miejscem, gdzie zatrudnienie mogli znaleźć uczeni niewygodni dla systemu. Wykłady prowadzili tu na przykład: Izydora Dąbska, Marian Plezia, Władysław Tatarkiewicz, Roman Ingarden. Od 1954 roku z wydziałem związał się Karol Wojtyła, który ożywił badania KUL-u silnym impulsem antropologicznym jako przeciwwagą dla typowego dla tomizmu podejścia kosmocentrycznego, co wkrótce zaowocowało wypracowaniem realistycznej koncepcji „personalizmu etycznego"16. Lata stalinowskie to czas izolacji wydziału, ale jednocześnie okres kształtowania stylu myślenia charakterystycznego dla środowiska KUL-u oraz ukierunkowania badań; wtedy to do publikacji zostaje przygotowana znacząca dla tomizmu praca Traktat o człowieku św. Tomasza z Akwinu w tłumaczeniu i opracowaniu prof. S. Swieżawskiego (książka przeleżała w wydawnictwie kilka lat i ukazała się dopiero w roku 1956).

Jak wspomniano, dla dialogu z marksizmem ważna była dekada po październiku 1956 roku. Filozofia polska, dzięki „odwilży”, mogła ponownie zacząć się rozwijać wielokierunkowo, a i w samym marksizmie wykształciły się wtedy dwa nurty: scjentystyczny i humanistyczny (po 1968 roku nazywany też rewizjonistycznym). Przedstawicielem pierwszego, bardziej zdogmatyzowanego, był na przykład Zdzisław Cackowski, drugi, bardziej otwarty reprezentowali między innymi: Adam Schaff, Leszek Kołakowski, Tadeusz Maciej Jaroszewski, Bronisław Baczko, Janusz Kuczyński, Tadeusz Płużanski, Krzysztof Pomian, Stefan Morawski, Marek Fritzhand (niektórzy z filozofów tego nurtu, na przykład Kołakowski, przeszli potem na stanowiska krytyczne wobec marksizmu). Wspomnianą

13 Zob. Adam Schaff, Marksizm a jednostka ludzka, Warszawa 1956, 242 (podaję za: Kowalczyk, Człowiek w poszukiwaniu wartości, 91).

${ }_{14}$ Zob. Marks, Engels, Manifest.

${ }^{15}$ Kowalczyk, Człowiek w poszukiwaniu wartości, 86.

16 Zob. Stanisław Janeczek, Filozofia na KUL-u. Nurty - idee - osoby (Lublin: RW KUL 1999), 119. 
dekadę uważa się za okres najbardziej twórczy; to czas autentycznego dialogu $\mathrm{z}$ marksistami ${ }^{17}$. Koncentrowano się na dwóch kwestiach: (1) metodologii filozofii oraz (2) wybranych tezach systemu z uwzględnieniem ich konsekwencji. Bardziej liberalna polityka władz PRL-u pozwoliła na zorganizowanie w 1957 roku dwóch spotkań między studentami wydziałów filozoficznych KUL i UW poświęconych społecznej roli filozofii oraz pojęciu materii. Na podstawie udostępnionego podsumowania pierwszego spotkania, którego dokonali ze strony KUL-u wówczas mgr Antoni B. Stępień, a ze strony UW doc. Leszek Kołakowski, łatwo dostrzec skalę pojęciowych nieporozumień, w które uwikłana była dyskusja. Kołakowski pisał: „,filozofia tomistyczna [...] jest uzależniona od Objawienia i wobec tego jest poniżeniem rozumu ludzkiego [...], w tomizmie człowiek jest najniższą inteligencją, a w marksizmie - najwyższym wytworem materii" ${ }^{\prime 18}$. Od 1958 roku Koło Studentów KUL zaczęło regularnie organizować Tygodnie Filozoficzne, które były okazją wymiany poglądów między przedstawicielami różnych nurtów filozoficznych. Zainaugurował je ówczesny dziekan Wydziału Filozofii dr hab. Mieczysław Krąpiec programowym wykładem na temat tomizmu. Spotkania były zazwyczaj bardzo burzliwe. Profesor Antoni B. Stępień wspomina, że uczestnikom Tygodni zdarzało się toczyć spory na tematy filozoficzne i światopoglądowe do późnej nocy.

$\mathrm{Na}$ jakości dialogu negatywnie zaważyły wydarzenia marcowe, które spowodowały, że wymiana poglądów znowu weszła w fazę pozorowaną, ograniczoną do roli propagandowej. Chociaż po 1970 roku władza PRL, której zależało na ociepleniu stosunków z Zachodem, zaczęła przyzwalać na dyskusje dotyczące religii, chrześcijańskiej teorii człowieka i społeczeństwa, a w dowód otwartości zachęcała do organizowania zjazdów i konferencji naukowych, to było oczywiste, że w dyskusjach nie chodziło o rzetelną próbę zrozumienia strony przeciwnej. W związku z tym czynnik instrumentalizowania dialogu był znaczący ${ }^{19}$. Jak wspomina Stępień, prywatnie prowadzono ciekawe dyskusje, ale na poziomie publikacji stronę marksistowską obowiązywała jedyna słuszna wykładnia, której strzegła cenzura ${ }^{20}$. System władzy niezmiennie demonstrował siłę. Dobrym przykładem był zorganizowany w 1977 roku w Lublinie popisowy I Zjazd Filozoficzny PRL pod hasłem „Filozofia w służbie narodu i socjalizmu”"21. Znakiem tego czasu ponownego zideologizowania marksizmu stała się funkcja filozofa oficjalnego. Zasłużyli na nią jedynie niektórzy profesorowie marksistowscy, ci, którzy pełnili zadania reprezentacyjne i ideologiczne w PRL-u, także w okresie stanu wojennego. Chudy pisze:

17 Zob. Stępień, „Rys rozwoju filozofii marksistowskiej”; Chudy, „Postaci marksizmu”.

${ }^{18}$ Cyt. za: Stępień, „Rys rozwoju filozofii marksistowskiej”, 29.

19 Zob. na przykład Jerzy W. Gałkowski, „Problem pracy w dialogu chrześcijańsko-marksistowskim w Polsce po II wojnie światowej”, w: Wobec filozofii marksistowskiej, 145-170.

${ }^{20}$ Zob. Stępień, „Rys rozwoju filozofii marksistowskiej”.

${ }^{21}$ Zob. Chudy, „Postaci marksizmu”, 105. 
Jest gorzkim paradoksem, że do najbardziej eksponowanych wówczas „filozofów urzędowych" socjalizmu należeli między innymi etycy. W pracach tych autorów (między innymi w T. Jaroszewskiego Traktacie o naturze ludzkiej, 1980) znajdowały się cytaty z przemówień pierwszych sekretarzy PZPR i partii z krajów ościennych, „filozoficzne" uzasadnienie obecnego kursu politycznego czy etyczne usprawiedliwienia niesprawiedliwości (ekonomicznej, politycznej, społecznej itp.) ${ }^{22}$.

Niektórzy filozofowie KUL-u w dyskusji z marksistami próbowali wskazywać na pewne wspólne elementy obu teorii (marksistowskiej i tomistycznej), takie jak: realizm, klasyczna definicja prawdy, negacje aprioryzmu i sfery idealnej jako obiektywnie istniejącej. Ksiądz prof. Stanisław Kowalczyk dostrzegał punkty styczne w uznawaniu przez obie strony wartości życia społecznego, pracy, wolności, sprawiedliwości, w przezwyciężaniu wad społecznych i alienacji ${ }^{23}$, inni badacze wydziału traktowali te próby łączenia jako zawodne ze względu na to, że porównywane elementy należały do różnych ontologicznych, epistemologicznych i antropologicznych systemów. Stępień twierdził, że:

Poszukiwanie na siłę podobieństw nie jest dobrym sposobem prowadzenia dialogu. Dialog powinien być przede wszystkim nastawiony na wzajemne, lepsze zrozumienie Drugiego, z którym - mimo różnicy zdań - stanowię lub mogę stanowić wspólnotę: wspólnotę poszukujących prawdy lub wspólnotę członków tego samego narodu ${ }^{24}$.

Przykładem nieporozumienia na tle tomistycznej interpretacji antropologii i metafizyki może być krytyka książki Mieczysława A. Krąpca Ja - człowiek (1974) podjęta przez Zdzisława Cackowskiego w pracy Człowiek jako podmiot działania praktycznego i poznawczego (1979) ${ }^{25}$. Obaj badacze, Cackowski i Krąpiec, widzieli człowieka jako podmiot działania, niemniej jednak inaczej tę kwestię rozumieli. Według Krąpca substancjalny podmiot jest centrum różnych aktów, a dla Cackowskiego - funkcją działań.

Ostatni okres, a więc po 1980 roku, można nazwać czasem wewnątrzdoktrynalnej otwartości marksizmu, ze względu na podejmowane przez marksistowskich akademików próby adaptacji doktryny do innych kierunków filozoficznych ${ }^{26}$. Korzysta się między innymi z prac szkoły frankfurckiej, Hegla, Kanta, Poppera, fenomenologii, dekonstrukcjonizmu Derridy, a nawet personalizmu chrześcijańskiego. Zauważalne jest odchodzenie od kategorii prawdy absolutnej, relatywizowanie treści systemu, w szczególności z zakresu antropologii

22 Tamże, 103-104.

${ }^{23}$ Zob. Stanisław Kowalczyk, „Marksistowska koncepcja wyzwolenia człowieka a chrześcijaństwo", w: Oblicza dialogu, 136-156.

${ }^{24}$ Antoni B. Stępień, „Tomizm wobec marksizmu w Polsce”, w: Oblicza dialogu, 118.

${ }_{25}$ Zob. analizę tej polemiki: Wojciech Chudy, „Człowiek jako podmiot albo człowiek jako funkcja”, Znak 33 (1981): 620-635.

${ }^{26}$ Zob. Chudy, „Postaci marksizmu”. 
i etyki ${ }^{27}$. Osłabieniu ulega mianowicie prymat kolektywu nad jednostką, a przyporządkowanie człowieka do biegu dziejów przestaje być istotne. Człowiek to homo relativus: nie ma stałej natury, a w związku z tym nie istnieją wartości, które powinien realizować ${ }^{28}$. Dyskusja $\mathrm{z}$ tymi post-marksistowskimi poglądami przekroczyła ramy PRL-u.

\section{Antropologia zintegrowana: Wydział Filozofii Chrześcijańskiej a misja KUL-u}

KUL był pierwszym uniwersytetem, który po II wojnie światowej reaktywował działalność i jedynym katolickim uniwersytetem w bloku komunistycznym. W konsekwencji ze szkoły o charakterze regionalnym, jaką był przed wojną, zmienił się w uczelnię o zasięgu krajowym ${ }^{29}$. O ile przed 1939 roku miał wypełnić lukę na edukacyjnej mapie wschodniej Polski oraz służyć integracji wschodnich i zachodnich ziem kraju, po wojnie stał się intelektualnym centrum kultury chrześcijańskiej. Mecenasami uniwersytetu zostali polscy katolicy (w kościołach prowadzono zbiórki na tak zwaną tacę), studentów rekrutowano ze wszystkich stron Polski, a absolwenci, mimo trudności, znajdowali pracę w ośrodkach naukowych, twórczych, wydawnictwach, domach kultury i szkolnictwie całego kraju. Patronat nad reaktywowaną uczelnią sprawował Kościół katolicki w Polsce w osobach polskich biskupów. Szczególną opieką KUL otoczony został przez ks. prymasa kard. Stefana Wyszyńskiego, który wspomagał oraz inspirował liczne przedsięwzięcia naukowe i wydawnicze. Zabiegał o to, by kultura polska nie została pozbawiona chrześcijańskiego dziedzictwa.

Tak określona misja uniwersytetu akcentuje zasadniczy element alternatywnej pedagogiki: zwrócenie uwagi na rolę religii w życiu człowieka i kulturze narodu. W realizację misji zaangażował się również Wydział Filozofii, podejmujący między innymi dyskusję $\mathrm{z}$ ateistycznymi tezami marksizmu. Prowadzono więc badania $\mathrm{z}$ zakresu teorii bytu i człowieka, filozofii religii oraz problematyki relacji wiary i rozumu ${ }^{30}$. Rozpoczęto też intensywne prace $z$ dziedziny historii filozofii, w szczególności dotyczące średniowiecza ${ }^{31}$. Dostrzegano konieczność wypracowania metod badawczych oraz określenia statusu wiedzy filozoficznej, a także wyjaśnienia jej autonomii, zarówno w stosunku do wiary, jak i nauk przyrodniczych, ze względu na to, iż marksiści podkreślali silny związek filozofii z tymi naukami, zarzucając tomizmowi uwikłanie religijne, a ponadto utrzymywali,

\footnotetext{
27 Zob. tamże.

28 Zob. tamże.

29 Zob. Mieczysław A. Krąpiec, Człowiek - kultura - uniwersytet (Lublin: RW KUL 1982), 385.

30 Zob. na przykład prace z filozofii religii Zofii J. Zdybickiej.

31 Zob. na przykład badania Stefana Swieżawskiego, Mariana Kurdziałka.
} 
że marksizm jest światopoglądem naukowym. Filozofowie KUL uważali tymczasem, że światopogląd jest wiedzą subiektywną, a nie naukowąą ${ }^{32}$, podobnie też widzieli problem ideologii. Jak łatwo zauważyć, różnica między oboma stanowiskami rysowała się już w samym definiowaniu filozofii i jej roli poznawczej. Filozofowie KUL podkreślali prawdziwościowe cele poznania, marksiści filozofię łączyli z ideologią, w służbie przemiany stosunków społecznych w kierunku wyznaczonym przez władze partyjne.

W tej sytuacji zasadne było pytanie: na jakiej płaszczyźnie prowadzić dialog ${ }^{33}$. KUL-owcy nie chcieli być „partnerami” dyskusji sprowadzonej do poziomu światopoglądu czy dogmatu, oceniali ją jako nierzetelną i z góry zakładającą zakłamania czy uproszczenia, szukali więc możliwości dialogu na płaszczyźnie filozoficznej, jakkolwiek ze świadomością, że od marksistów trudno wymagać „czystej” filozofii.

W związku z kwestią światopoglądu należy wyjaśnić, że misję uniwersytetu (wyrażoną choćby przymiotnikiem „katolicki” w nazwie uczelni) pojmowano w duchu komplementarności wiary i rozumu, z zachowaniem rozdzielności obu porządków. Chodziło o zaakcentowanie chrześcijańskiej postawy i wychowawczej funkcji uczelni, ze względu na świadomość ścisłego związku między sferą moralną a rozwojem intelektualnym człowieka. Inspiracja światopoglądowa (katolicka) nie dotyczyła jednak ani przedmiotu, ani metody badań naukowych, a więc indoktrynacji nauki ${ }^{34}$. „Katolickość” uczelni zapowiadała oczywiście jakąś formę dyskusji światopoglądowej z marksistami (ważną choćby ze względu na konieczność współistnienia $\mathrm{w}$ jednym społeczeństwie ludzi o różnych przekonaniach), niemniej jednak badacze zabiegali o konstruktywny dialog merytoryczny.

W 1958 roku ówczesny dziekan Wydziału Filozofii dr hab. Mieczysław A. Krąpiec podczas wspomnianego wykładu zauważył, że uniwersytet szanuje prawa człowieka do wolności i rozwoju moralno-intelektualnego i zaznaczył, że uczelnia, jako demokratyczna wspólnota ludzi oddanych nauce, dba o równoprawne traktowanie wszystkich dyscyplin: nie ma wydziałów „wyższych”, które innym dyktowałyby jakieś idee. Uczony podkreślił, że badania prowadzi się w duchu wolności, a zatem są one podporządkowane jedynie prawdzie obiektywnej i właściwym regułom metodycznym. Zwrócił też uwagę na zaangażowanie uczelni w tworzenie teoretycznych podstaw humanizmu i demokracji. Wiele lat później, już jako rektor KUL-u, w trakcie inauguracji roku akademickiego 1981/1982 wyjaśniał, że „katolickość” uczelni oznacza programowe realizowanie dwóch zadań: badań nad dziedzictwem religijnym (kulturą chrześcijańską) i tych dziedzin kultury, które się z nim łączą, oraz kształcenia duchowieństwa i katolików (uczelnia

${ }^{32}$ Zob. na przykład prace Stanisława Kamińskiego, Alberta M. Krąpca.

${ }^{33}$ Zob. Krąpiec, „Dialog?”.

${ }^{34}$ Zob. Krąpiec, Człowiek - kultura - uniwersytet, 393. Praca jest zbiorem tekstów pochodzących najczęściej z okolicznościowych wykładów wygłaszanych przez o. prof. Krąpca. Przytoczone informacje pochodzą z tekstu wywiadu w niej zamieszczonego, a udzielonego przez Krąpca Czesławowi Dąbrowskiemu w 1978 roku z okazji sześćdziesięciolecia KUL-u. 
była otwarta również dla wszystkich chętnych) ${ }^{35}$. Tę misję realizowały zarówno wydziały kościelne (teologia i prawo), jak i świeckie (filozofia i humanistyka).

Wydział Filozofii KUL, który powstał z inicjatywy ówczesnego biskupa lubelskiego i wielkiego kanclerza KUL - Stefana Wyszyńskiego, rozpoczął działalność dopiero 10 listopada 1946 roku (wcześniej filozofię można było studiować na Wydziale Humanistycznym). Pierwszym dziekanem był ks. Józef Pastuszka (w 1952 roku musiał odejść na skutek restrykcji władz stalinowskich), a w grupie studentów znalazły się 72 osoby $^{36}$. Wydział tworzyło wielu znamienitych badaczy: Jerzy Kalinowski, Stanisław Kamiński, Mieczysław Albert Krąpiec, Marian Kurdziałek, Stefan Swieżawski, Karol Wojtyła ${ }^{37}$. Tworzące się struktury wydziału ostatecznie zaowocowały licznymi katedrami: metafizyki, antropologii filozoficznej, etyki, filozofii kultury, filozofii przyrody, filozofii religii, estetyki. Przez pewien czas na wydziale były nawet specjalizacje psychologii i socjologii. Filozoficzne zaplecze dla niefilozoficznych dyscyplin pozwoliło na bardziej wszechstronne traktowanie zagadnień, które stanowiły centrum badań ${ }^{38}$. W myśl humanizmu deklarowanego w statucie uczelni wydział obejmował refleksją zarówno warunki kulturowe, jak i samego człowieka. Program badań i celów sformułowano do 1966 roku, przede wszystkim jednak stworzono narzędzia metodologiczne dla uprawiania realistycznej filozofii. W latach 1967-1980 poszerzono pole badań, dając początki systemowi realistycznej filozofii klasycznej (dlatego dziś mówi się

35 Zob. tamże, 355-381. Informacje pochodzą z tekstu wykładu inaugurującego rok akademicki 1981/1982.

${ }^{36}$ Zob. Janeczek, Filozofia na KUL-u, 61-67.

${ }^{37} \mathrm{Na}$ pierwszy okres działalności WFCH KUL składają się prace badawcze: J. Kalinowskiego, S. Kamińskiego, M.A. Krąpca, M. Kurdziałka, S. Swieżawskiego, K. Wojtyły oraz ich uczniów. Do grona studentów M.A. Krąpca należą wtedy między innymi: M. Gogacz, F. Wilczek, A.B. Stępień, M. Jaworski, W. Stróżewski, B. Dembowski, Z.J. Zdybicka, S. Kowalczyk, S. Majdański, T. Kwiatkowski. Na wydziale pracują w tym czasie również: J. Iwanicki, W. Wąsik, K. Kłósak, F. Tokarz, W.F. Bednarski, A. Korcik, którzy jednak nie włączają się bezpośrednio w pracę nad programem realistycznej filozofii. W okresie drugim (1950-1966) do badań prowadzonych przez szkołę przyłączają się: B. Bejze, S. Kowalczyk, T. Styczeń, E. Morawiec, E. Wolicka, J. Gałkowski, T. Żeleźnik, S. Wielgus, E.I. Zieliński, K. Wójcik, F. Krauze, a także: A. Wawrzyniak, J. Herbut, A. Bronk, A. Szostek, S. Kiczuk, R. Weksler-Waszkinel, A. Buczek, A. Woźnicki. Z trzecim okresem (1967-1980) związana jest działalność naukowa także nowej grupy filozofów: U. Żegleń, T. Szubki, A. Maryniarczyka, H. Kieresia, P. Jaroszyńskiego, K. Wroczyńskiego, P. Moskala, W. Dłubacza, I. Deca, J. Sochonia, H. McDonalda, W. Chudego oraz kolejnego pokolenia absolwentów związanych z następującymi katedrami Wydziału Filozofii: metafizyki (na przykład P. Gondek, A. Robaczewski, K. Stępień, B. Czupryn, Z. Pańpuch, A. Gudaniec, P. Tarasiewicz, P. Skrzydlewski), etyki (na przykład B. Chyrowicz, M. Czachorowski, A. Wierzbicki, K. Krajewski, J. Frydrych, A. Szuta, J. Kłos, M. Borkowska-Nowak), historii filozofii (na przykład M. Ciszewski, A. Kijewska, M. Podbielski, S. Janeczek, J. Judycka, P. Gutowski, I. Ziemiński, P. Gut, M.S. Zięba, P. Sajdek), logiki i teorii poznania (na przykład S. Judycki, J. Wojtysiak, A. Gut, P. Kawalec, M. Walczak, A. Lekka-Kowalik, R. Wierzchosławski, P. Kulicki, P. Garbacz, B. Czarnecka-Rej, A. Salamucha). Informacje podaję za: Janeczek, Filozofia na KUL-u.

${ }^{38}$ Zob. Krąpiec, Człowiek - kultura - uniwersytet, 362. 
o Polskiej Szkole Filozofii Klasycznej). Po roku 1981 roku wydział kontynuuje wielokierunkowe prace badawcze.

Dyskusja z marksistami dotyczyła przede wszystkim formuły humanizmu. Ten, z którym identyfikowało się środowisko KUL-u, miał charakter integralny i wyrażał się między innymi ukierunkowaniem badań i pracy wychowawczej na cztery istotne dziedziny kultury: człowieka jako jej twórcę i podmiot oraz naukę, sztukę, kulturę, moralnośćc ${ }^{39}$. Chodziło o pokazanie człowieka w pełnym wymiarze, a nie - jak robili to marksiści - wybiórczo. Człowiek nie tylko jest twórcą narzędzi czy ulega alienacji, ale jako osoba góruje nad przyrodą swoim rozumem, miłością, aktami decyzji, twórczością, żyje w relacjach społecznych i pragnie zrozumieć sens swojego życia, cierpienia i śmierci ${ }^{40}$. Osnową tego humanizmu była - jak mawiał prof. Krąpiec - umiejętność dostrzeżenia w ludzkim istnieniu dwóch wątków: natury i kultury (potrzeby człowieka wyznacza natura, a zaspokaja kultura). Zdaniem filozofa humanizm to umiejętne łączenie różnych sfer kultury, a w pracy wychowawczej uwzględnianie zarówno zasad moralnych, jak i potrzeb życia religijnego czy intelektualnego ${ }^{41}$.

Krąpiec nie tylko w planie strategicznym uczelni (jako dziekan Wydziału Filozofii, potem rektor), ale i w planie intelektualnym (jako uczony) bardzo zabiegał o antropologiczny profil uniwersytetu i program studiów nad człowiekiem. W 1968 roku podczas wystąpienia $\mathrm{z}$ okazji 50-lecia KUL upominał się o to, jako o konieczność wynikającą z potrzeby przeciwwagi dla studiów przyrodniczych i cywilizacji technicznej. Antropologia była dla niego i obowiązkiem badawczym, i edukacyjnym, ponieważ uczelnia nie była związana z programem prac PAN-u i uniwersytetów państwowych, a więc cieszyła się większą swobodą w badaniach i problemem człowieka mogła się zajmować także w perspektywie nadprzyrodzonej i religijnej ${ }^{42}$. W 1968 roku Krąpiec sformułował postulat wielodyscyplinarnych badań nad człowiekiem i niedługo wykład $\mathrm{z}$ antropologii filozoficznej stał się dla studentów Wydziału Filozoficznego obowiązkowy (w latach 1957-1981 na wydziale funkcjonowały cztery specjalizacje: teoretyczna, społeczna, psychologiczna i przyrodnicza). Osadzenie antropologii filozoficznej w programach studiów i obszarze badań filozoficznych Krąpiec postrzegał jako warunek humanizacji tych studiów i tych badań, a zarazem jako przyczynek do rozwoju nie tylko filozofii, ale i całej humanistyki ${ }^{43}$. Sam realizował ten postulat w swoich badaniach i licznych publikacjach, na przykład Ja - człowiek (1974), Człowiek $i$ prawo naturalne (1975), U podstaw rozumienia kultury (1991). Warto zaznaczyć, że uczony nie traktował wiedzy antropologicznej jedynie jako przedmiotu badań akademickich; był przekonany, że jest ona potrzebna człowiekowi w życiu

\footnotetext{
39 Zob. tamże, 376.

40 Zob. tamże, 370.

${ }^{41}$ Zob. tamże, 389-397 (informacje pochodzą z przytaczanego już wywiadu z roku 1978).

${ }^{42}$ Zob. tamże, 351 (wykład M.A. Krąpca z roku 1968).

${ }^{43}$ Zob. tamże, 353.
} 
codziennym. O praktycznym wymiarze myślenia filozoficznego, w szczególności filozofii człowieka, profesor mówił podczas spotkania na Zamku Królewskim w Warszawie, 14 lipca 1988 roku, prowadząc swego rodzaju dialog z Michaiłem Gorbaczowem na temat suwerenności człowieka, państwa i narodu. Marksiści uznawali kolektyw (państwo) za pierwszego suwerena, tymczasem Krąpiec, wtedy rektor KUL, podkreślał, że to człowiek jako osoba - podmiot świadomego i wolnego działania, byt o wymiarze transcendentalnym - obdarzony jest suwerennością, której część może przekazać państwu ${ }^{44}$.

\section{Dwie antropologie: dyskusja z tezami antropologii marksistowskiej}

Nie ma potrzeby szczegółowo omawiać antropologii formułowanej przez uczonych Wydziału Filozofii i jej znaczenia dla pedagogiki ze względu na dostępność prac poświęconych temu zagadnieniu ${ }^{45}$. Skoncentrujmy się więc na kilku kwestiach, które wyróżniają tę antropologię od marksistowskiej. Pod uwagę weźmiemy trzy fundamentalne wyznaczniki marksizmu: materializm, ateizm oraz dialektykę. Nie będziemy przy tym wchodzić w istotę różnic, wynikających z definiowania materializmu przez samych marksistów ani inne niuanse dyktowane historycznym rozwojem tej filozofii ${ }^{46}$.

Marksizm postrzegał rzeczywistość jako materię (lub pochodną materii) naznaczoną zmiennością: byt to jedność przeciwieństw, to walka i rozpadanie prowadzące do kolejnej niestabilnej jedności. Dialektyczność oznaczała, że „materia jest w stanie wytworzyć radykalnie nową formę bytu, niedającą się przewidzieć na podstawie jej praw, przekraczającą materię w jej treści i strukturze" ${ }^{47}$. W związku z tym człowiek, jego świadomość, akty intelektualne i wolitywne czy wszelkie działania kulturowe jako pochodne materii były dla marksistów uwikłane w kołowrót przemian rzeczywistości. Nie zgadzając się z tą wizją filozofowie KUL-u, między innymi A.B Stępień, podkreślali na przykład, że teoria ta rodzi rozmaite wątpliwości, między innymi dotyczące tego, w jaki sposób mogą istnieć spójne całości bytowe,

${ }^{44}$ Zob. Zofia J. Zdybicka, „Filozof wierny prawdzie o rzeczywistości”, w: Wierność rzeczywistości. Ksiega pamiątkowa z okazji jubileuszu 50-lecia pracy naukowej na KUL o. prof. Mieczysława A. Krapca, red. Zofia J. Zdybicka (Lublin: PTTA 2001), 12.

${ }^{45}$ Poprzednie, a więc drugie, Seminarium Polskiej Myśli Pedagogicznej było poświęcone filozofii realistycznej, w tym filozofii rozwijanej na Wydziale Filozofii Chrześcijańskiej KUL. Zob. na przykład wykład wygłoszony przez ks. prof. Andrzeja Maryniarczyka „Antropologiczno-metafizyczne podstawy adekwatnej teorii wychowania w ujęciu twórców Filozoficznej Szkoły Lubelskiej”, Polska Myśl Pedagogiczna 2 (2016): 103-116.

${ }^{46}$ Zob. opracowanie tego zagadnienia: Stępień, „Rys rozwoju filozofii marksistowskiej”.

${ }^{47}$ Zob. tenże, „Materializm dialektyczny - filozofia marksizmu”, w: Wobec filozofii marksistowskiej, 53. 
w szczególności byty o wysokiej organizacji wewnętrznej, w tym - byty osobowe, podmiotujące swoje akty i mające świadomość własnego „ja” ${ }^{\prime 2}$. Marksistowski materializm, chociaż nie był skrajny i nie zaprzeczał istnieniu ducha, świadomość postrzegał jednak jako własność ciała i produkt materii (jej treść stawała się odbiciem materii), a nie - jak w tomizmie - jako funkcję duszy. Według marksistów dusza nie istniała, a czynnikiem konstytuującym człowieka był społeczny sposób ludzkiego bycia (zamiast „duchowy” najczęściej używali określenia „społeczny”) ${ }^{49}$.

Marksiści zawsze ujmowali człowieka w perspektywie społeczności. To ona nadawała sens ludzkiemu życiu ${ }^{50}$. Ich zdaniem człowiek rozwijał się w społeczeństwie i poprzez społeczeństwo, a dzięki pracy i mowie tworzył swój własny - ludzki - świat, który nie był już światem czysto przyrodniczym. Tożsamość człowieka uznawali za funkcję działań społecznych, a pracę (produkcję) za czynniki tworzące człowieczeństwo ${ }^{51}$. Tymczasem w ujęciu tomistycznym człowiek pojmowany jako jednostkowy byt substancjalny o rozumnej naturze (jako osoba) posiada strukturę materialno-duchową i jest podmiotem działania oraz źródłem wartości. Rozwój człowieka wymaga kontekstu społecznego, niemniej jednak społeczność nie nadaje sensu ludzkiemu bytowi. Okazuje się ontycznie „słabsza” niż człowiek: ma charakter relacyjny (nie jest bytem substancjalnym ani nie wykazuje żadnej immanentnej jedności działania). Fundamentem wspólnoty osób są relacje międzyosobowe ze względu na transcendentalne (koniecznościowe) relacje każdego człowieka do ostatecznego celu ${ }^{52}$. Bytowe tłumaczenie wartości osoby dostarcza kryterium oceny porządku społecznego. Budowanie relacji społecznych jest owocem procesu aktualizowania potencjalności. Realne relacje osobowe nie są czymś "gotowym”, ale wymagają wysiłku stałego rozumienia i akceptacji wartości drugiego człowieka jako osoby. Ich ontyczna kruchość potwierdza wagę wychowania jako formacji charakteru i kształtowania sumienia.

Marksistowska apersonalistyczna antropologia nie dawała podstaw do indywidualnego, w pełni zintegrowanego rozwoju człowieka, według tomizmu ten rozwój jest natomiast fundamentem wszelkiej pracy pedagogicznej. W wychowaniu, jak nadal podkreślają tomiści, chodzi o wprowadzanie zmian (to znaczy o aktualizowanie potencjalności), które modyfikują sposób istnienia człowieka. Należy podkreślić, że kształtowaniu podlega nie sama osobowa tożsamość (ta jest niezmienna), ale potencjał rozwojowy charakterystyczny dla osoby: człowiek urzeczywistniając swoje człowieczeństwo, bardziej staje się człowiekiem, choć ciągle jest tą samą

${ }^{48}$ Zob. tamże, 55.

49 Zob. Bocheński, Marksizm-leninizm, 103.

${ }^{50}$ Zob. Zofia J. Zdybicka, „Marksizm bez ateizmu? Czy ateizm jest istotnym składnikiem marksizmu?", w: Oblicza dialogu, 172. Zob. w szczególności polemikę autorki z marksistą J. Kuczyńskim na temat jego pracy Uniwersalizm jako metafilozofia (1990) - tamże, 157-175.

${ }^{51}$ Jerzy W. Gałkowski, „Tworzenie się człowieka przez pracę?”, w: Wobec filozofii marksistowskiej, 108.

52 Zob. Mieczysław A. Krąpiec, Człowiek i prawo naturalne (Lublin: RW KUL 1999). 
osobą. Proces duchowego rozwoju wyraża się zdolnością budowania relacji społecznych opartych na wzajemnym szacunku osób i miłości. Marksizm, sankcjonując walkę klas, negował ideę miłości jako fundamentu społeczeństwa ${ }^{53}$.

Kolejna różnica ważna dla teorii wychowania polegała na kwestii odmiennego rozumienia wartości. Marksiści w myśl relatywizmu aksjologicznego wszelkie zasady moralne traktowali jako przejściowe, w świetle materializmu historycznego ludzkie działanie miało społeczno-ekonomiczne determinacje. Jakkolwiek w późniejszej fazie dialogu niektórzy marksiści (na przykład Marek Fritzhand) próbowali dokonywać korekty $\mathrm{w}$ tej kwestii, dopuszczając istnienie pewnych stałych norm elementarnych (na przykład „nie zabijaj”, „nie kradnij” itp.), to zasadnicza - relatywistyczna - interpretacja moralności została utrzymana. Jedyną stałą wartością był postęp na drodze do komunizmu: cała kultura, w tym sztuka i wychowanie, miała służyć realizacji celów politycznych ${ }^{54}$. Tomiści natomiast, uznając bytowe rozumienie wartości i stałą naturę człowieka, zdecydowanie sprzeciwiali się relatywizmowi aksjologicznemu ${ }^{55}$. Ich zdaniem wartości nie tylko ujawniają się w ludzkich aktach poznawczych, uczuciowych, dążeniowych, ale także je wzbudzają. Przy czym jedne wartości mają charakter względny (instrumentalny), inne absolutny, w związku z ich rolą doskonalącą człowieka jako osobę w dziedzinie poznania, moralnych wyborów, twórczości i religii. Stanowisko tomistyczne $\mathrm{w}$ tej kwestii uwyraźniało potrzebę integralnego wychowania jako alternatywy dla pedagogiki formułowanej na podstawie marksizmu. Według tomistów prawda, dobro, piękno i świętość rozwijają wewnętrznie człowieka dlatego, że są zespołem cech bytu, które domagają się od niego czynnej odpowiedzi ${ }^{56}$. Prawda, posiadając moc normatywną, jest wartością najbardziej podstawową i ujawnia się w całej ludzkiej aktywności kulturowej.

Na szczególną uwagę, ze względu na alternatywność w stosunku do marksizmu, zasługuje tomistyczne rozumienie świętości jako „nabudowanej” na innych wartościach ${ }^{57}$. Ta koncepcja jest wyraźną konsekwencją całej metafizycznej teorii: bytu i człowieka, sformułowanej na Wydziale Filozofii KUL. Składają się na nią metafizyczne twierdzenia dotyczące: istnienia Boga jako racji istnienia wszystkiego, relacji Boga do stworzeń, przygodności człowieka i jego naturalnej religijności. W związku z tym w teorii integralnego wychowania dostrzegano znaczącą rolę religii w osiąganiu dojrzałości przez człowieka ${ }^{58}$. Prowadzona przez badaczy KUL analiza religii ujawniała jej związek z moralnością: akty religijne

${ }^{53}$ Specyficzną próbę asymilacji idei miłości w marksizmie podjął M. Fritzhand w pracy Etyka i walka klas. Mianowicie twierdził, że jedyną sankcją nienawiści klasowej może być tylko miłość człowieczeństwa. Podaje za: Kowalczyk, Człowiek w poszukiwaniu wartości, 91.

${ }^{54}$ Zob. Bocheński, Marksizm-leninizm, 109.

${ }_{55}$ Zob. Stanisław Kamiński, Jak filozofować? (Lublin: TN KUL 1989), 302, 305.

${ }^{56}$ Zob. tamże, 303.

${ }^{57}$ Zob. Zofia J. Zdybicka, Człowiek i religia (Lublin: TN KUL 1993), 311-313.

${ }^{58}$ Zob. tamże. 
wymagają od człowieka świadomych decyzji, gdyż przez nie, czyniąc dobro lub zło, podejmując wysiłek lub nie, człowiek wraca do Boga lub odeń odchodzi. Nie można jednak - jak zauważali uczeni - redukować religii tylko do moralności czy wymiaru kulturowego. Religia jest relacją człowieka do Boga w porządku bytowym, a nie tylko aksjologicznym, uwarunkowanym społecznie i historycznie. Świętość polega na połączeniu się człowieka z Bogiem przez miłość. Nie jest to stan, ale proces ogarniający człowieka całościowo. Z jednej strony doskonaleniu ulega ludzkie postępowanie, $\mathrm{z}$ drugiej - następuje przemiana ontyczna: uwalnianie się od determinacji materii w miarę rozwoju aktywności duchowej ${ }^{59}$.

O ile wychowanie - według tomizmu - ma więc umacniać perspektywy ponadczasowe ludzkiego istnienia, to $\mathrm{w}$ marksizmie, którego trwałymi elementami są ateizm i krytyczna ocena religii, takiej potrzeby w ogóle nie formułowano. W związku z tym, że marksiści upatrywali genezy religii w lęku wobec sił przyrody, w niskim poziomie wiedzy na temat przyrody oraz alienacji ekonomicznej (religia była wyrazem wypaczeń ustroju ekonomiczno-społecznego), ich zdaniem rozwój społeczny, prowadząc do dezalienacji, miał automatycznie powodować wygasanie życia religijnego ${ }^{60}$. Teorii wyzwolenia człowieka nadawali charakter społeczno-ekonomiczny. Wartości religijne, traktowane przez tomistów jako istotny czynnik doskonalący człowieka, przez marksistów nie były uznawane. W późniejszym okresie PRL-u, gdy władza dopuszczała publiczne dyskusje wokół kwestii religijnych, zaczęto dostrzegać jedynie ich znaczenie kulturowe. Wyrazem tego był między innymi projekt wprowadzenia do programu edukacji w szkołach zajęć z religioznawstwa, ale i on - jak zauważyła Zdybicka - miał w gruncie rzeczy służyć dalszej ateizacji społeczeństwa ${ }^{61}$.

Reasumując, dyskusja z filozofią marksistowską, którą podjęli badacze Wydziału Filozofii KUL w okresie PRL-u, w gruncie rzeczy koncentrowała się na formule humanizmu, a więc kwestii istotnej dla pedagogiki. Spór z marksizmem o wizję człowieka był prowadzony bądź wprost jako dyskusja z tezami filozoficznymi, bądź nie wprost, to znaczy poprzez założenia programowe, instytucjonalne samej uczelni, której Wydział Filozofii był częścią, a przede wszystkim przez niezależne badania i formułowanie filozoficznej teorii człowieka. Antropologia wypracowywana na wydziale wyznaczała podstawy alternatywnej myśli wychowawczej w stosunku do marksistowskiej pedagogiki.

Dziś, po ponad 25 latach od zmian ustrojowych w Polsce, o polskim marksizmie pisze się już w czasie przeszłym. Niemniej jednak nie można zapominać o roli tej filozofii w kształtowaniu polskiej kultury. Trudno nie zgodzić się

59 Zob. tamże, 315.

${ }^{60}$ Zob. Zofia J. Zdybicka, „Człowiek - zbawca człowieka? Uwagi o marksistowskiej teorii religii”, w: Wobec filozofii marksistowskiej, 171-200 oraz Kowalczyk, Człowiek w poszukiwaniu wartości, 92.

${ }^{61}$ Zob. Zdybicka, Człowiek - zbawca człowieka? oraz taż, Człowiek i religioznawstwo (Lublin: RW KUL 1988). 
z Władysławem Tatarkiewiczem ${ }^{62}$, gdy zauważa, iż socjalizm był pierwszą formą ustroju społecznego, która nie tylko została zaprojektowana przez filozofów, ale i zrealizowana w praktyce społecznej, a to oznacza, że pedagogika inspirowana marksizmem miała wpływ na wychowanie pokolenia Polaków.

Streszczen i e: W artykule zostaje podjęty temat filozoficznych podstaw pedagogiki alternatywnej w stosunku do marksistowskiej. Przedmiotem refleksji jest aktywność badawcza realizowana przez Wydział Filozofii Chrześcijańskiej Katolickiego Uniwersytetu Lubelskiego (KUL) w okresie, gdy władzę w Polsce sprawowali komuniści. Dzięki antropologii filozoficznej formułowanej na wydziale działalność wychowawcza, niezależna od ideologicznej indoktrynacji związanej z ówczesnym systemem władzy, mogła znaleźć potrzebny fundament teoretyczny. Artykuł składa się z czterech części. W pierwszej zostają przedstawione realia polityczne dialogu. Jak wiadomo, KUL - jedyny katolicki uniwersytet w krajach komunistycznych - mimo że działał pod silną presją ze strony władz PRL-u, był ważnym centrum kultury chrześcijańskiej w kraju i realizował inny, a mianowicie oparty na wartościach chrześcijańskich, model wychowania. W drugiej części artykułu omawia się pięć etapów trwającej przez blisko 40 lat dyskusji między filozofami KUL a marksistami - ich wyznacznikiem były zmiany polityczne w kraju w latach: 1944, 1950, 1956, 1968, 1981, 1989. Trzecia część analizy poświęcona jest modelowi humanizmu integralnego realizowanego przez KUL, z zaznaczeniem roli badań prowadzonych na Wydziale Filozofii. Rozważania kończy omówienie tez antropologii filozoficznej formułowanej na KUL-u, wybranych ze względu na jej różnice w stosunku do trzech fundamentalnych wyznaczników marksizmu: materializmu, ateizmu oraz dialektyki.

Słow a klu c zowe: marksizm, tomizm, pedagogika, antropologia filozoficzna, humanizm integralny, Wydział Filozofii Chrześcijańskiej Katolickiego Uniwersytetu Lubelskiego

\section{Bibliografia}

Bocheński, Józef M. Marksizm-leninizm. Nauka czy wiara? Komorów: Wyd. „Antyk - Marcin Dybowski”, 1999.

Chudy, Wojciech. „Człowiek jako podmiot albo człowiek jako funkcja”. Znak 33 (1981): 620-635.

Chudy, Wojciech. „Postaci marksizmu i ich ewolucja w powojennej Polsce”. W: Oblicza dialogu. $Z$ dziejów i teorii dialogu: chrześcijanie - marksiści w Polsce, red. Antoni B. Stępień, Tadeusz Szubka, 91-112. Lublin: RW KUL, 1992.

Gałkowski, Jerzy W. „Problem pracy w dialogu chrześcijańsko-marksistowskim w Polsce po II wojnie światowej”. W: Wobec filozofii marksistowskiej. Polskie doświadczenia, red. Antoni B. Stępień, 145-170. Lublin: TN KUL, 1990.

Gałkowski, Jerzy W. „Tworzenie się człowieka przez pracę?”. W: Wobec filozofii marksistowskiej. Polskie doświadczenia, red. Antoni B. Stępień, 105-118. Lublin: TN KUL, 1990.

„Historia KUL” [hasło], http://www.kul.pl/w-polsce-ludowej,art_15518.html, dostęp: 10.04.2017. Janeczek, Stanisław. Filozofia na KUL-u. Nurty - idee - osoby. Lublin: RW KUL, 1999.

Kamiński, Stanisław. Jak filozofować? Lublin: TN KUL, 1989.

${ }^{62}$ Podaję za: Chudy, Postaci marksizmu, 103. 
Kowalczyk, Stanisław. Człowiek w poszukiwaniu wartości. Elementy aksjologii personalistycznej. Lublin: Wydawnictwo KUL, 2006.

Kowalczyk, Stanisław. „Marksistowska koncepcja wyzwolenia człowieka a chrześcijaństwo”. W: Oblicza dialogu. Z dziejów i teorii dialogu: chrześcijanie - marksiści w Polsce, red. Antoni B. Stępień, Tadeusz Szubka, 136-156. Lublin: RW KUL, 1992.

Krąpiec, Mieczysław A. Człowiek i prawo naturalne. Lublin: RW KUL, 1999.

Krąpiec, Mieczysław A. Człowiek - kultura - uniwersytet. Lublin: RW KUL, 1982.

Krąpiec, Mieczysław A. „Dialog?”. W: Wobec filozofii marksistowskiej. Polskie doświadczenia, red. Antoni B. Stępień, 9-20. Lublin: TN KUL, 1990.

Marks, Karol, Fryderyk Engels. Manifest komunistyczny. Warszawa: Jirafa Roja, 2011.

Maryniarczyk, Andrzej. „Antropologiczno-metafizyczne podstawy adekwatnej teorii wychowania w ujęciu twórców Filozoficznej Szkoły Lubelskiej”. Polska Myśl Pedagogiczna 2 (2016): 103-116.

Oblicza dialogu. Z dziejów i teorii dialogu: chrześcijanie - marksiści w Polsce, red. Antoni B. Stępień, Tadeusz Szubka. Lublin: RW KUL, 1992.

Stępień, Antoni B. „Materializm dialektyczny - filozofia marksizmu”. W: Wobec filozofii marksistowskiej. Polskie doświadczenia, red. Antoni B. Stępień, 37-60. Lublin: TN KUL, 1990.

Stępień, Antoni B. „Rys rozwoju filozofii marksistowskiej i problem dialogu filozoficznego z marksizmem od roku 1945”. W: Wobec filozofii marksistowskiej. Polskie doświadczenia, red. Antoni B. Stępień, 21-59. Lublin: TN KUL, 1990.

Stępień, Antoni B. „Tomizm wobec marksizmu w Polsce”. W: Oblicza dialogu. Z dziejów i teorii dialogu: chrześcijanie - marksiści w Polsce, red. Antoni B. Stępień, Tadeusz Szubka, 113-118. Lublin: RW KUL, 1992.

Stępień, Antoni B. „Wobec marksistowskiej teorii człowieka”. W: Wobec filozofii marksistowskiej. Polskie doświadczenia, red. Antoni B. Stępień, 61-88. Lublin: TN KUL, 1990.

Wobec filozofii marksistowskiej. Polskie doświadczenia, red. Antoni B. Stępień. Lublin: TN KUL, 1990.

Zdybicka, Zofia J. Człowiek i religia. Lublin: TN KUL, 1993.

Zdybicka, Zofia J. Człowiek i religioznawstwo. Lublin: RW KUL, 1988.

Zdybicka, Zofia J. „Człowiek - zbawca człowieka? Uwagi o marksistowskiej teorii religii”. W: Wobec filozofii marksistowskiej. Polskie doświadczenia, red. Antoni B. Stępień, 171-200. Lublin: TN KUL, 1990.

Zdybicka, Zofia J. „Filozof wierny prawdzie o rzeczywistości”. W: Wierność rzeczywistości. Księga pamiątkowa z okazji jubileuszu 50-lecia pracy naukowej na KUL o. prof. Mieczysława A. Krąpca, red. Zofia J. Zdybicka, 5-16. Lublin: PTTA, 2001.

Zdybicka, Zofia J. „Marksizm bez ateizmu? Czy ateizm jest istotnym składnikiem marksizmu?”. W: Oblicza dialogu. Z dziejów i teorii dialogu: chrześcijanie - marksiści w Polsce, red. Antoni B. Stępień, Tadeusz Szubka, 157-175. Lublin: RW KUL, 1992. 